\title{
Learning media for calculating perimeter of plane figures in edugame for elementary school
}

\author{
Dwi Nugraheny ${ }^{1^{*}}$, Riski Mulia Prakasa ${ }^{2}$, Novera Marsda Riny ${ }^{3}$ \\ ${ }^{1,2}$ Program Studi Informatika, Institut Teknologi Dirgantara Adisutjipto \\ ${ }^{3}$ Program Studi Psikologi, UIN Sunan Kalijaga
}

\begin{tabular}{l}
\hline \hline Article Info \\
\hline Article history: \\
Received March 27, 2020 \\
Accepted May $3^{\text {rd }}, 2020$ \\
Published May 11, 2020 \\
\hline
\end{tabular}

\section{Keywords:}

Edugame

Elementary School

Learning

Perimeter

Plane Figures

\begin{abstract}
PT)
Learning is an interaction process among students, teachers, and the sources in learning environment. Learning media is an integral part from the whole system and learning process, which means that the learning media is a crucial element and it determines the learning activity. As one of a learning medias, multimedia animation gives a fun impression and helps learning process in remembering. The process to calculate perimeter of plane figures for 3 rd grade students in elementary school will be easier using a multimedia application that is interesting and interactive. This research aims to create a learning application to calculate the perimeter of plane figures in edugame. This edugame contains a tutorial to solve the perimeter of plane figures and some exercises with various plane figures. Through this edugame, the students can find out where the error lies when calculating the perimeter of plane figures. This application has tested using a questionnaire with 17 correspondents who are expert users. They are elementary school teachers with the average score result 2.8 , which have an interval score criteria "Good". Meanwhile, the second try out did through a youtube platform which was gained 64 views and 16 comments. The users commonly left comments such as "This application is very useful".
\end{abstract}

\section{Corresponding Author:}

Dwi Nugraheny

Program Studi Informatika, Institut Teknologi Dirgantara Adisutjipto

Janti Road, Blok R, Lanud Adisutjipto Yogyakarta

Email: *henynug@gmail.com

\section{INTRODUCTION}

According to UU Sisdiknas Tahun 2003 Bab 1 Pasal 1, [1] Learning is an interaction process between students, teachers, and learning sources in a study environment. Learning activities are defined as individual interactions with their environment. The environment in this case is other objects that allow individuals to gain experiences or knowledge, either new experiences or knowledge or something that has been obtained or discovered previously but it gains attention again to a person, thus it possibly could be an interaction [2].

A learning media is an integral part from the whole system and learning process, it means that the learning media is a crucial element and it defines the learning activity. Multimedia animations give fun impressions and help learning process in remembering [3]. Game that intended to educate can be used as one of the education medias that has a learning pattern called learning by doing [4].

Learning method that utilizes Information Technology in order to make the learning atmosphere is more interactive and fun to students and it can be an alternative to do the learning activities [5][6][7] in a written journal [8].

In a written journal [6], learning using animation E-Learning can be a learning tool to teach using electronic applications, media, Internet, Intranet or other computer network medias. In addition, computers and Internet networks which play a role in e-learning is the brainware that is creating content (text, images, video, animation) and user/users of e-learning (teachers and students). It should be noted in making animated e-learning, that the content should be included in accordance with the curriculum that is used by the school to be used for teaching and learning in schools. In a written journal [8], Interactive learning media is the media which is more effective so that the user can feel that practical learning is more fun and can stimulate users desire of learning. The pattern is the process of recognizing an object based on data that already exists to distinguish various patterns with different size and geometry of each pattern is obtained. 
Calculations on plane figures are part of elementary school students' mathematical theory for 3rd grade. One of the things that students in 3rd grade of elementary school learns is to find out the perimeter of plane figures. Plane figures have some various forms, therefore the students often have trouble in completion process and accuracy to calculate the perimeter of plane figures.

Based on the description above, this study will be made to calculate the perimeter of several plane figures for 3rd grade of elementary school students. This application has created in a form of edugame, therefore the students can study while playing in interactive way. This edugame contains a tutorial to solve the perimeter of plane figures and some exercises with various plane figures. Through this edugame students can find out where the error lies that is formed in confirmations, only if the students are not careful in calculating the perimeter of plane figures. Through this edugame, it is hoped that the students are not bored and they will be motivated to solve the problem of calculating plane figures' perimeter.

\section{RESEARCH METHOD}

\subsection{Steps to Build a System}

Steps to build Edugame: Calculating the Perimeter of Plane Figures, as figured in Fig 1.

a. In Fig 1, it starts with understanding the learning problem that has been faced by Elementary School students, especially on $3^{\text {rd }}$ grade, to calculate the perimeter of plane figures. The problem that has been faced by Elementary School students is how the image visualization is to calculate the perimeter of plane figures that previously in the book then to be adapted in another media that is computer, as an edugame. With edugame, it is expected that students will not be bored, but they will be motivated to get to know how to calculate the perimeter of plane figures, through various forms with provided scores.

b. The next development step is designing non-functional needs that needed by the system; for hardware and software. The software supporter is a sound, it is needed so the edugame feels more motivated to users or students. The sound configuration according to Sungkono (1999) in article [9], music is a sound harmonization that has a meaning and high artistic value. Sound effect that usually abbreviated as (FX) is an imitation or real sound that shows imagination energy and experience about the situation that is currently shown [10].

c. If the designing of functional needs and non-functional have done, then the next step is implementation, in the form of coding and testing the system.

d. After the testing has done, there is a re-evaluation. If the evaluation result is fulfilled as the design, then the system development is finished. But, if the result is opposite and the test still has a lot of mistakes, then there should be a repairment.

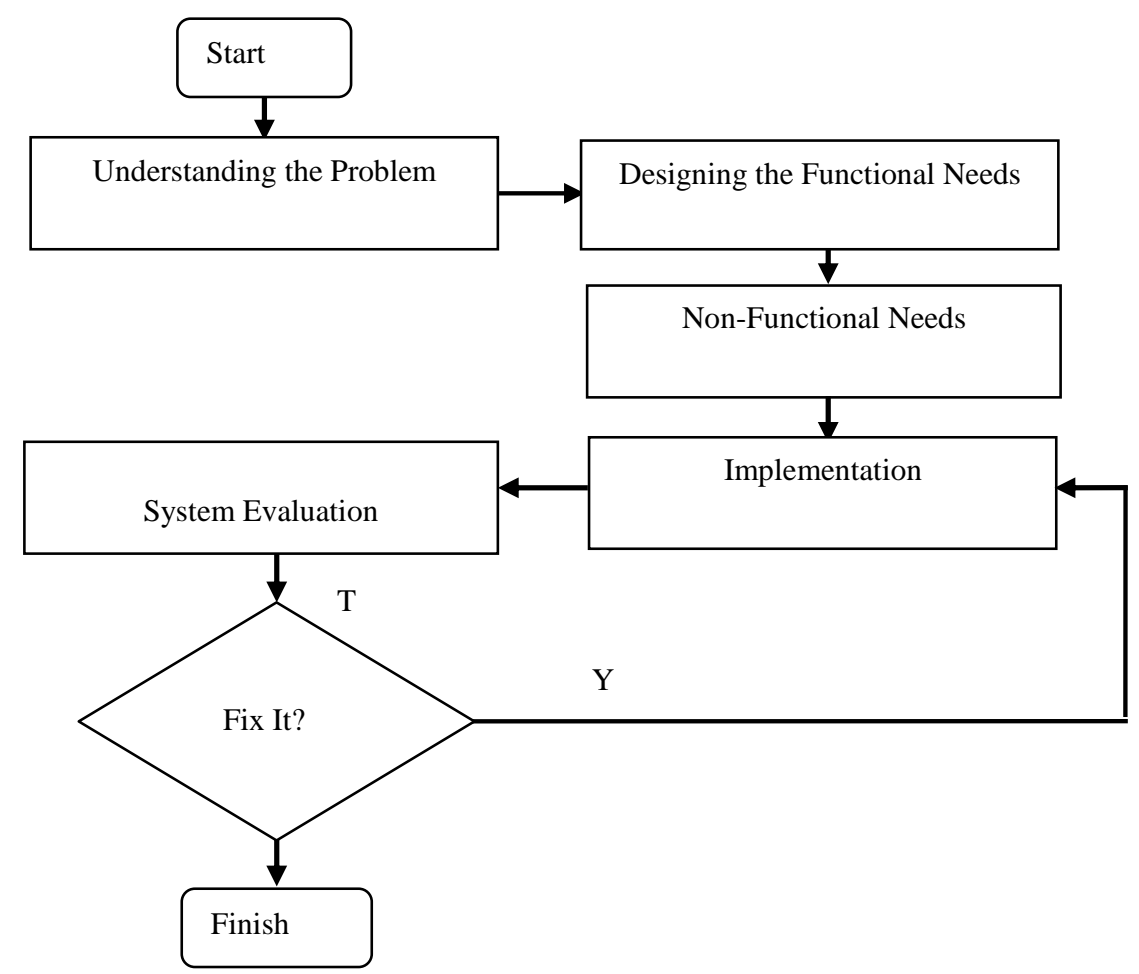

Fig 1. Steps to Build Edugame System by Calculating the Perimeter of Plane Figures 


\subsection{The Working Principle of System}

Perimeter of plane figures is the sum of the lengths of its bounding sides. Fig 2 explains the concept of plane figure's formula [11]:

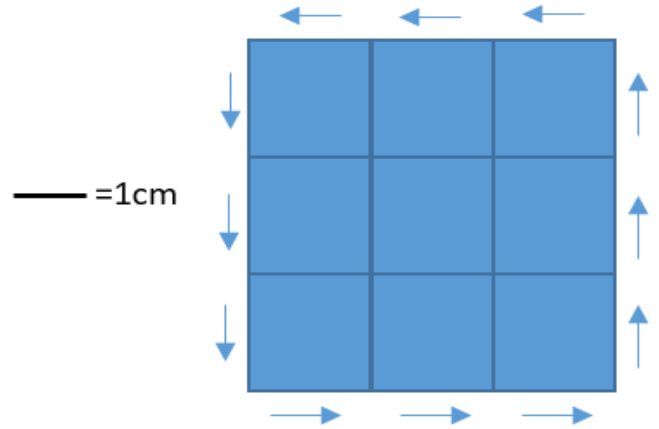

Fig.2 Concept to Calculate the Perimeter of Plane Figures

The formula of square's perimeter $K=$ side + side + side + side ... [11]. $1+1+1+1+1+1+1+1+1+1+1+1=12 \mathrm{~cm}$.

The plane figure's perimeter result on Fig. 2 is $12 \mathrm{~cm}$.

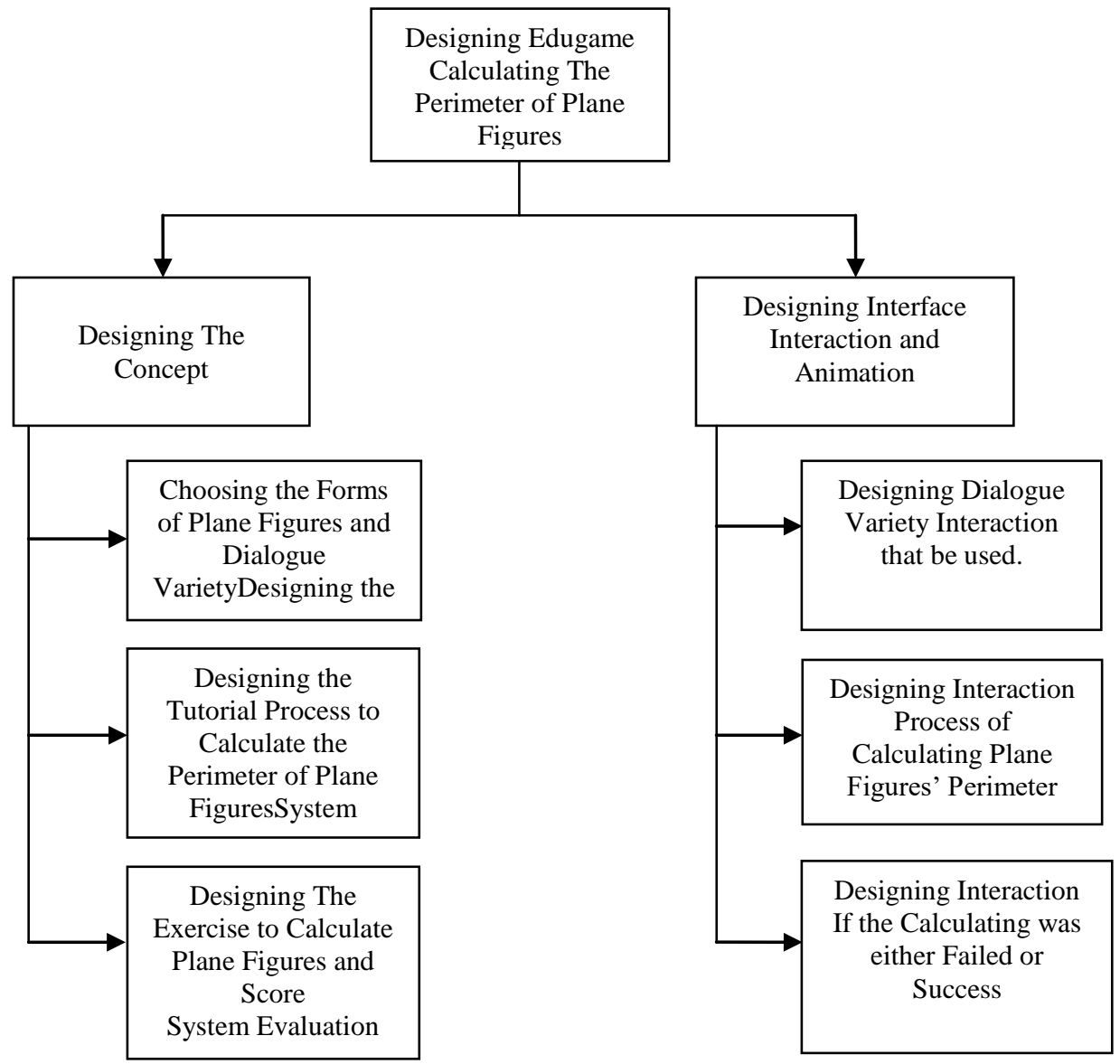

Fig 3. System Design Steps to Calculate the Perimeter of Plane Figures

Fig 3 explains the designing steps on calculating the perimeter of plane figures. Starts from 2 (two) main designs; Concept Design and Interface Interaction and Animation Design.

In the Concept Design, there are some designs:

a. Choose the Forms of Plane Figures and Dialogue Variety/ Interaction Style, those are dialogues between computer and user[12]. Some of the dialogue varieties that used are WIMP (Windows, 
Icons, Menus, Pointers), Interface, sound (as backsound and character's voice), and point and click.

b. Designing a Tutorial of Plane Figures Perimeter's Calculating Process. Tutorial in visualization presented suitably as the tutorial from Elementary School's book, that is "Tema 7 for $4^{\text {th }}$ grades" book [11].

c. Designing the exercise to give a training to students in order to finish calculating the perimeter of plane figures. The exercise designed as edugame. If students could finish the exercise correctly, then the students will get scores as how it determined.

Meanwhile, in the Interface Interaction and Animation Design, there are some designs:

a. Designing interaction of dialogue variety that is used. The dialogue variety that has been selected then designed to interact between systems and users.

b. Designing interaction process to calculate the perimeter of plane figures. It is because the application is an edugame, so if there was a fault during the calculating process, there will be a reaction from system with some confirmations and information so the users or students can find out where the error is.

\section{RESULTS AND ANALYSIS}

The result from calculating perimeter of plane figures system can be seen on Fig. 4 (a) and (b), Fig. 5, and Fig. 6 (a) and (b).

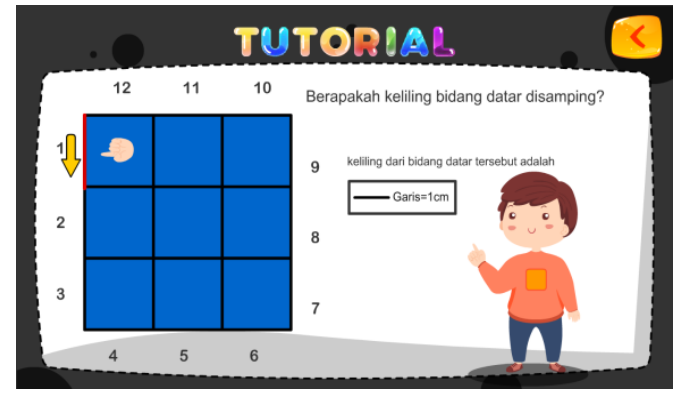

(a)

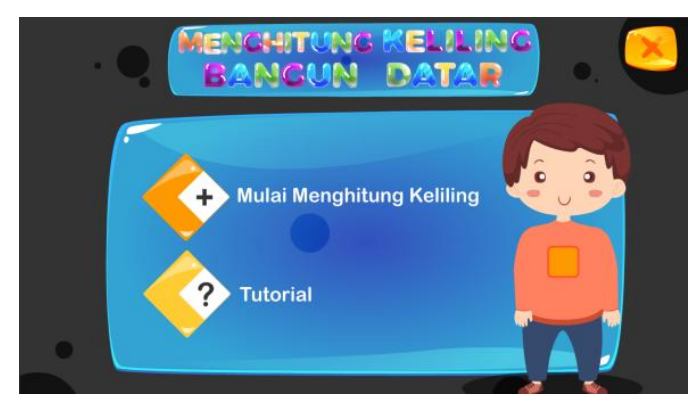

(b)

Fig 4. The opening view from system (a) and (b) Tutorial on how to calculate the Perimeter of Plane Figures.

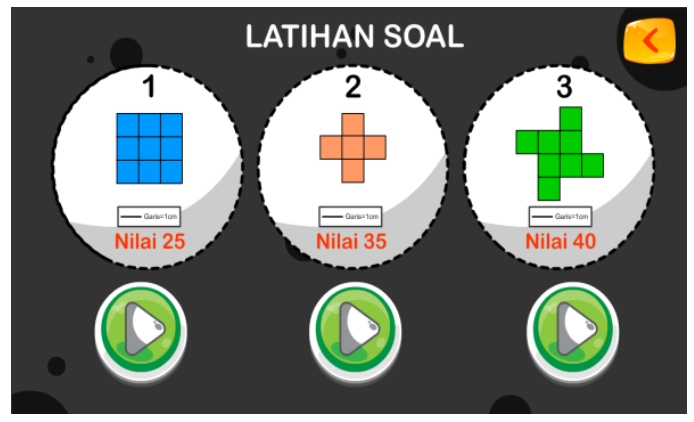

Fig 5. Exercise on various forms of plane figures with scores.

On Fig 4 there is 2 (two) menu options; Mulai Menghitung Keliling and the tutorial. If the users or students still do not understand on how to calculate perimeter of plane figures, they can choose the tutorial menu. But, if the users or students already understand on how to calculating perimeter of plane figures, then the users of students can choose the menu Mulai Menghitung Keliling. On Fig 5 is exercise on various forms of plane figures with scores. Scores based on unique plane figures, if it is very unique then the score is high. 


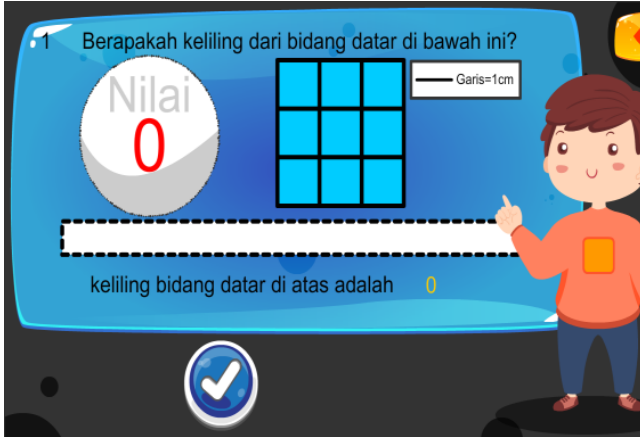

(a)

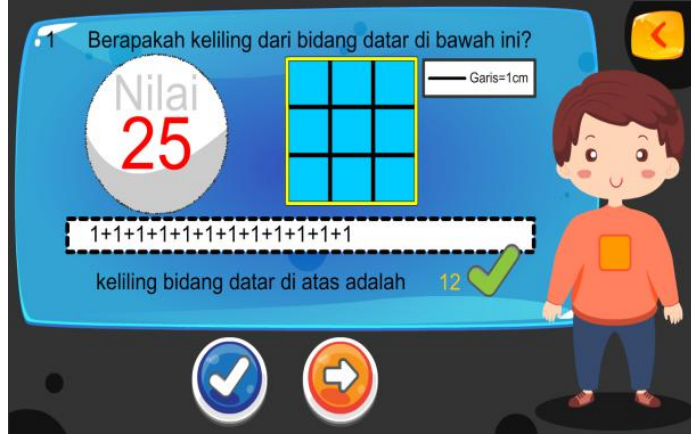

(b)

Fig 6. Completing Process to Calculate the Perimeter of Plane Figures (a) and (b)

Fig 6 (a) and (b) explain the completing process to calculate the perimeter of plane figures. On that process, users or students pointed to the lines that formed as perimeter of plane figures. If the users or students mistakenly choose the wrong lines, then the system will give a ringtone signal wrong and the wrong lines' color that previously pointed will change to red, with a confirmation message as showed on Fig 7.

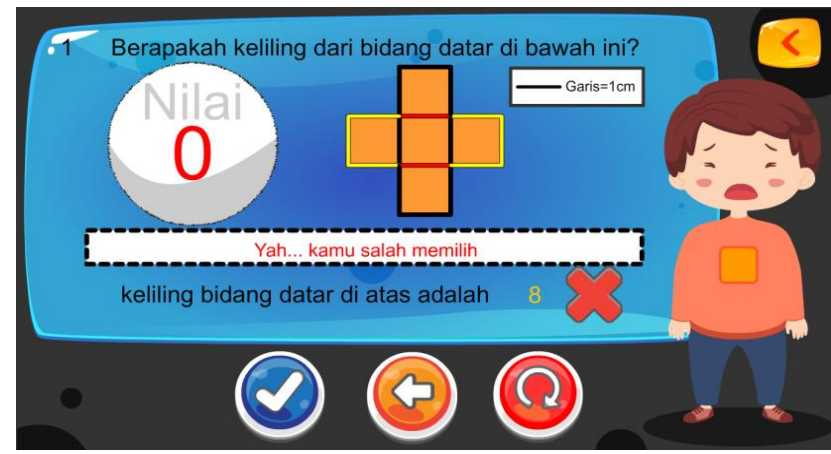

Fig 7. The view if there is an error and the confirmation message

During the process of calculating perimeter of plane figures, if there is an error as showed on Fig 7, the the users or students will be asked to repeat the calculation by pressing the Repeat symbol button. But, if the users or students do not want to calculate again, then they can press the left arrow button back to the main menu.

\subsection{Functional Test}

Table 1 is the result of functional Test to Main Menu and Exercise Form. The result of Functional Test is to Main Menu and Exercises on Table 1, all of the buttons on user interface menu's view are functioning as expected, so the Functional Test is in Tutorial Form on Table 2.

Table 1. Functionality Test on Main Menu and Exercise Form

Functional Test on Main Menu

\begin{tabular}{cllll} 
Number & \multicolumn{1}{c}{ Function } & Expected Results & \multicolumn{1}{c}{ Test } & Information \\
\hline 1 & $\begin{array}{l}\text { Button Starts } \\
\text { to Calculate } \\
\text { Perimeter } \\
\text { Button Tutorial }\end{array}$ & $\begin{array}{l}\text { Lead to Exercise } \\
\text { Form }\end{array}$ & $\begin{array}{l}\text { Lead to Exercise } \\
\text { Form }\end{array}$ & Valid \\
& Lead to Tutorial & Lead to Tutorial & Vorm \\
& Button Close & Exit from & Application and & Exit from \\
& & $\begin{array}{l}\text { Application and } \\
\text { Show }\end{array}$ & Valid \\
& & Confirmation & Fonfirmation & \\
& & Form & & \\
\hline
\end{tabular}

Functional Test on Exercise Form 


\begin{tabular}{|c|c|c|c|c|}
\hline Number & Function & Expected Results & Test & Information \\
\hline \multirow[t]{3}{*}{1} & $\begin{array}{l}1^{\text {st }} \text { Arrow } \\
\text { Button }\end{array}$ & $\begin{array}{l}\text { Leads to } 1^{\text {st }} \text { Exercise } \\
\text { Form }\end{array}$ & $\begin{array}{l}\text { Leads to } 1^{\text {st }} \text { Exercise } \\
\text { Form }\end{array}$ & Valid \\
\hline & $\begin{array}{l}2^{\text {nd }} \\
\text { Arrow } \\
\text { Button }\end{array}$ & $\begin{array}{l}\text { Leads to } 1^{\text {st }} \text { Exercise } \\
\text { Form }\end{array}$ & $\begin{array}{l}\text { Leads to } 1^{\text {st }} \text { Exercise } \\
\text { Form }\end{array}$ & Valid \\
\hline & $\begin{array}{l}3^{\text {rd }} \\
\text { Arrow } \\
\text { Button }\end{array}$ & $\begin{array}{l}\text { Leads to } 1^{\text {st }} \text { Exercise } \\
\text { Form }\end{array}$ & $\begin{array}{l}\text { Leads to } 1^{\text {st }} \text { Exercise } \\
\text { Form }\end{array}$ & Valid \\
\hline \multirow[t]{4}{*}{2} & $\begin{array}{l}\text { Exercise } \\
1,2 \text { and } 3\end{array}$ & $\begin{array}{l}\text { Users' action with } \\
\text { perimeter lines on } \\
\text { exercise interact with } \\
\text { each other. } \\
\text { If there is an error } \\
\text { during the } \\
\text { calculating, then it } \\
\text { shows an error } \\
\text { confirmation and the } \\
\text { wrong perimeter } \\
\text { lines will change into } \\
\text { red along with the } \\
\text { wrong tone. }\end{array}$ & $\begin{array}{l}\text { Users' action with } \\
\text { perimeter lines on } \\
\text { exercise interact with } \\
\text { each other. } \\
\text { If there is an error } \\
\text { during the } \\
\text { calculating, then it } \\
\text { shows an error } \\
\text { confirmation and the } \\
\text { wrong perimeter } \\
\text { lines will change into } \\
\text { red along with the } \\
\text { wrong tone. }\end{array}$ & Valid \\
\hline & & $\begin{array}{l}\text { b. Undo Button to re- } \\
\text { calculate. }\end{array}$ & $\begin{array}{l}\text { b. Undo Button to re- } \\
\text { calculate. }\end{array}$ & Valid \\
\hline & & $\begin{array}{l}\text { c. Arrow Button Left } \\
\text { to go back to Main } \\
\text { Menu. }\end{array}$ & $\begin{array}{l}\text { c. Arrow Button Left } \\
\text { to go back to Main } \\
\text { Menu. }\end{array}$ & Valid \\
\hline & & $\begin{array}{l}\text { d. Tick Button to } \\
\text { confirm the obtained } \\
\text { scores. }\end{array}$ & $\begin{array}{l}\text { d. Tick Button to } \\
\text { confirm the obtained } \\
\text { scores. }\end{array}$ & Valid \\
\hline
\end{tabular}

Table 2. Functional Test on Tutorial Form

Functional Test on Tutorial Form

\begin{tabular}{|c|c|c|c|c|}
\hline Number & Function & Expected Result & Test & Information \\
\hline 1 & Arrow & $\begin{array}{l}\text { The arrow sign } \\
\text { automatically } \\
\text { runs to give a } \\
\text { clue on the } \\
\text { traversed } \\
\text { perimeter to be } \\
\text { calculated. }\end{array}$ & $\begin{array}{l}\text { The arrow sign } \\
\text { automatically } \\
\text { runs to give a } \\
\text { clue on the } \\
\text { traversed } \\
\text { perimeter to be } \\
\text { calculated. }\end{array}$ & Valid \\
\hline 2 & Process Area & $\begin{array}{l}\text { Automatically } \\
\text { filled with the } \\
\text { score of line } \\
\text { process of plane } \\
\text { figures. }\end{array}$ & $\begin{array}{l}\text { Automatically } \\
\text { filled with the } \\
\text { line process of } \\
\text { plane figures. }\end{array}$ & Valid \\
\hline 3 & Output Area & $\begin{array}{l}\text { Automatically } \\
\text { filled with the } \\
\text { sum result of } \\
\text { perimeter lines }\end{array}$ & $\begin{array}{l}\text { Automatically } \\
\text { filled with the } \\
\text { sum result of } \\
\text { perimeter lines }\end{array}$ & Valid \\
\hline
\end{tabular}


that traversed along with the score confirmation that obtained. that traversed along with the score confirmation that obtained.

\subsection{Users Test}

During users test, there are 2 (two) tests for this application, through online media. There are a test that published on youtube channel and Online Questionnaire Test. Table 3 is the average results of the questionnaire responds from 10 (ten) questions. Average respondents about the application included in "Good Category", with the average score result 2.8.

Table 3. Average Results from Questionnaire Responds Through Online Media

\begin{tabular}{|c|c|c|c|c|c|c|c|c|c|c|}
\hline \multirow{2}{*}{ Respondents } & \multicolumn{10}{|c|}{ Average Results from Questions } \\
\hline & U1 & $\mathrm{U} 2$ & U3 & U4 & U5 & U6 & U7 & U8 & U9 & U10 \\
\hline 1 & 2 & 2 & 2 & 3 & 3 & 3 & 2 & 3 & 3 & 3 \\
\hline 2 & 3 & 3 & 3 & 3 & 3 & 3 & 3 & 3 & 3 & 3 \\
\hline 3 & 3 & 2 & 3 & 3 & 3 & 3 & 3 & 3 & 3 & 3 \\
\hline 4 & 3 & 3 & 3 & 3 & 3 & 3 & 3 & 3 & 3 & 3 \\
\hline 5 & 3 & 2 & 3 & 3 & 3 & 3 & 3 & 3 & 3 & 3 \\
\hline 6 & 3 & 3 & 3 & 3 & 2 & 3 & 3 & 3 & 3 & 3 \\
\hline 7 & 2 & 3 & 3 & 2 & 3 & 2 & 3 & 3 & 3 & 2 \\
\hline 8 & 3 & 3 & 3 & 3 & 3 & 3 & 3 & 3 & 3 & 3 \\
\hline 9 & 3 & 3 & 2 & 2 & 2 & 2 & 2 & 3 & 3 & 3 \\
\hline 10 & 3 & 3 & 3 & 3 & 3 & 3 & 3 & 3 & 3 & 3 \\
\hline 11 & 3 & 2 & 3 & 3 & 3 & 3 & 3 & 3 & 3 & 3 \\
\hline 12 & 3 & 3 & 3 & 3 & 3 & 3 & 3 & 3 & 3 & 3 \\
\hline 13 & 3 & 3 & 3 & 3 & 3 & 3 & 3 & 3 & 3 & 3 \\
\hline 14 & 3 & 3 & 3 & 3 & 3 & 3 & 3 & 2 & 3 & 3 \\
\hline 15 & 2 & 1 & 3 & 2 & 3 & 2 & 3 & 2 & 2 & 2 \\
\hline 16 & 1 & 2 & 3 & 2 & 2 & 2 & 1 & 3 & 2 & 1 \\
\hline 17 & 3 & 2 & 3 & 3 & 3 & 3 & 3 & 3 & 3 & 3 \\
\hline $\begin{array}{l}\text { Average } \\
\text { Scores }\end{array}$ & 2,7 & 2,5 & 2,7 & 2,8 & 2,8 & 2,8 & 2,8 & 2,9 & 2,9 & 2,8 \\
\hline
\end{tabular}

On Figure 8 (a) and (b) are a graphic result from questionnaire responses based on the questions. According to the graphic result, questions about users and system are clear and can be easily understood, categorized as "Good". So there are the questions about easy-learning and user-friendly that categorized as "Good".

Intraksi pengguna dan sistem jelas dan dapat di mengerti ? 16 responses
Mudah Dipelajari dan Dioperasikan ?

17 responses

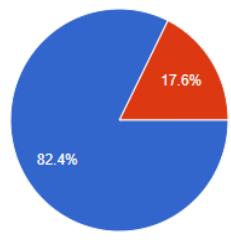

Baik Kurang Baik

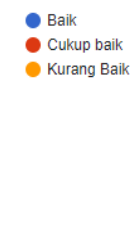

(a)

(b)

Fig 8. Graphic (a) and (b) are responds from the testing questionnaire through online youtube publish, as shown on Fig (a) and (b). 


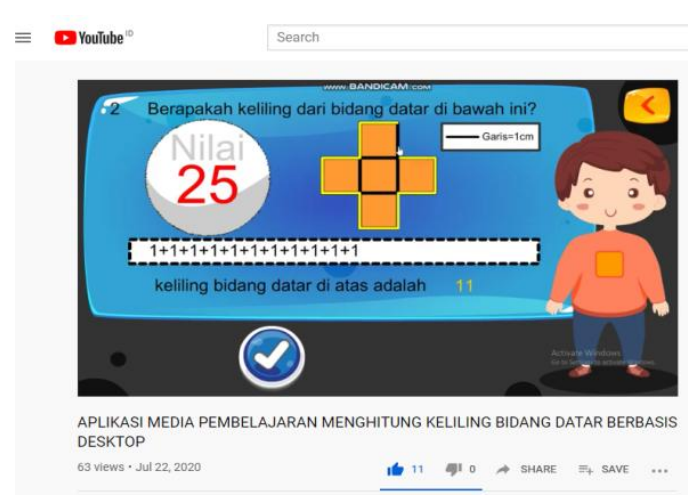

(a)

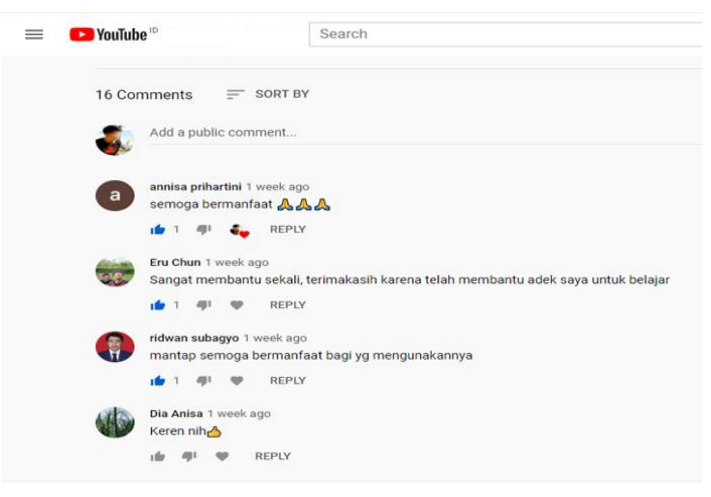

(b)

Fig 9. Testing through online youtube publish

On Figure 9 (a) and (b), there are application ratings by 63 (sixty three) viewers through youtube publish, gained average comments such as "This application is very useful".

\section{CONCLUSION}

Edugame calculates the perimeter of plane figures and the students are helped to understand the calculating process visually. The given score also motivates students to get the highest score. Edugame is user-friendly which is easy to operate with the tutorial that is provided on the Main Menu.

\section{REFERENCES}

[1] Dosen Pendidikan 2. (2021). https://www.dosenpendidikan.co.id/pengertian-pembelajaran-menurut-para-ahli diakses, Maret 2021.

[2] Aunurrahman, "Belajar dan Pembelajaran", Bandung: Alfabeta, 2013.

[3] Suheri, A., “Animasi Multimedia Pembelajaran”, Jurnal Media Teknologi, 2006.

[4] Handriyantini, E., "Permainan edukatif (educational games) berbasis komputer untuk siswa sekolah dasar Malang", Sekolah Tinggi Informasi \& Komputer Indonesia. 2009.

[5] Dimyati, dan Mudjiono.,’Belajar dan Pembelajaran”, Jakarta: PT. Rineka Cipta. 2009.

[6] N. D. Retnowati and M. G. Rahmawan, "Animasi E-Learning Pembelajaran Matematika Dan Fisika Bagi Siswa Sekolah Menengah Pertama Kelas 1,” Angkasa: Jurnal Ilmiah Bidang Teknologi, vol. 8, no. 2, p. 139, Aug. 2017.

[7] D. F. Pratama, E. N. Tamatjita, and D. Nugraheny. "Permainan Catur Inggris Berbasis Android Menggunakan Algoritma Minimax," Compiler, vol. 5, no. 2, Nov. 2016.

[8] [8] D. Nugraheny and A. D. Setiawan, "Interactive Media To Learn Identifying Patterns And Calculating Geometry Objects ( Case Study: Tk Aba Surya Melati, Yogyakarta)," Compiler, vol. 7, no. 2, p. 123, Oct. 2018.

[9] A. A. N. Bonai, D. Nugraheny, and H. Agustian, "Introduction to Yogyakarta Icons in The Game of Running Challenge," Compiler, vol. 8, no. 1, p. 35, Mar. 2019.

[10] Sungkono," Pengembangan Media Audio",. Yogyakarta: FIP UNY. 1999.

[11] Gunanto, Dhesy Adhalia, "ESPS Matematika", Erlangga, Jakarta. 2015.

[12] Dix, Finlay, Abowd and Beal, "Human-Computer Interaction”, Prentice Hall, 2004

[13] Sugiyono, "Metode Penelitian Kuantitatif, Kualitatif dan R \& D", Penerbit Alfabeta, Bandung. 2008.

[14] https://carasatu.web.id/rumus-bangun-datar/ (diakses 5 Agustus 2020).

[15] https://gurudigital.id/pengertian-contoh-dan-software-pembuat media interaktif. (diakses 7 Agustus 2020). 